\title{
EXTERNAL SYSTEMIC AND COMPARATIVE ARGUMENTS IN THE INTERPRETATION OF THE SLOVAK CONSTITUTIONAL COURT
}

\section{Katarína ŠMIGOVÁ ${ }^{1}$}

This contribution aims to analyze the interpretation methodology used by the Constitutional Court of the Slovak Republic in its decision from 4 July 2012 upon protection of property rights and a right to a fair trial. Focus is given to the external systemic interpretative method, especially to the use of caselaw of the European Court of Human Rights.

interpretation methodology

Constitutional Court of the Slovak Republic

European Court of Human Rights

\section{INTRODUCTION}

The presented article is devoted to one decision of the Constitutional Court of the Slovak Republic (hereinafter 'Slovak Constitutional Court' or 'Slovak CC') from 4 July 2012 dealing with the property rights protection and the consequences of executive immunity of a state as a challenge for the effective judicial protection (hereinafter also 'Slovak CC decision'). ${ }^{2}$

This article aims to analyse the interpretation methodology used by the Slovak CC. This specific decision was chosen because, at the first glance, it systematically provided reasoning of the Slovak CC. It summarised arguments of the claimant and relevant state bodies and subsequently presented its perspective based on historical, comparative, systemic, contextual, and even non-legal arguments. Moreover, without expressly naming it, the Slovak CC has also supported its arguments by scholarly works, application of general legal principles, and own case law. ${ }^{3}$ Finally, the decisive factor for selecting the decision

1 | Associate Professor, Institute of International and European Law, Faculty of Law, Pan-European University, Slovakia, katarina.smigova@paneurouni.com.

2 | Constitutional Court of the Slovak Republic, PL. ÚS 111/2011, finding from 4 July 2012.

3 | For details upon the methods of interpretation see Zoltan J Toth, The Methods of Statutory Interpretation in the Practice of the High Courts of Hungary. AnnalesUniversitatisMariae CurieSklodowska, Lublin - Polonia, vol 1, 2016, p. 173 et seq. 
has been the fact that one of the supreme judicial bodies has applied the international law institute of jurisdictional immunities of a state in a rather incomprehensible way compared to the case law of the international judicial bodies.

This article is divided into three main subsections. The first concentrates on the presentation of the factual and legal background of the case. The second points out the main argumentation line of Slovakia's highest state bodies, namely the Slovak Parliament and government, since these bodies are responsible for the adoption and application of the relevant legislation. The third deals with the reasoning of the Slovak Constitutional Court, focusing mainly but not exclusively on the comparative and external systemic arguments since the decision of the Slovak CC from 4 July 2012 has been based on a different approach towards execution immunities of a state being a part of jurisdictional immunities of a state rather than the decision of the International Court of Justice ${ }^{4}$ and the European Court of Human Rights (hereinafter 'ECtHR'. ${ }^{5}$ Unlike the above-mentioned international judicial bodies, the Slovak Constitutional Court has decided not to interpret immunities first of all as a procedural bar but preferred application of the principle of proportionality as if it was a substantive right. This principle is applied at the level of weighting, ${ }^{6}$ as a basic interpretative rule in the area of human rights protection. ${ }^{7}$

The selected decision includes the interpretation of several legal issues; nevertheless, the article especially brings together the interpretation of fundamental human rights, including references to the case law of international judicial bodies; therefore, other domestically important arguments have been intentionally left out, e.g. the legal substance of the objected legal norms or a difference between an administrator of state property, on the one hand, and the owner of state property, namely the Slovak Republic, on the other hand (elaborated within the so-called empirical argumentation line).

\section{FACTUAL AND LEGAL BACKGROUND AND ISSUE}

The proceedings before the Slovak Constitutional Court were triggered by a petition of the District Court Bratislava I (hereinafter 'District Court') which had issued a warrant of execution against the Slovak Republic, Ministry of Justice, to recover a claim granted for payment. Part of the required amount was paid, and the rest remained unpaid. ${ }^{8}$ Therefore, the District Court stayed the proceeding until the decision by the Slovak CC was adopted on the compliance of the relevant legal norms with the Constitution of the Slovak Republic and international treaties. This was because Slovakia is a monistic-like country in the case of the international treaties it ratified before 1 July 2001; and according to the

4 | E.g. International Court of Justice, Jurisdictional Immunities of the State, Germany v. Italy: Greece intervening, judgement of 3 February 2012.

5 | E.g. European Court of Human Rights, Al-Adsani v. UK, application no. 35763/97, judgement of 21 November 2001.

6 | Alexy, 2010, p. 50.

7 | European Court of Human Rights, Soeringv. the United Kingdom, application no. 14038/88, judgement of 7 July 1989 , para. 89.

8 | Zoltan J Toth, The Methods of Statutory Interpretation in the Practice of the High Courts of Hungary. Annales Universitatis Mariae Curie-Sklodowska, Lublin - Polonia, vol 1, 2016, p. 173 et seq., para I.2. 
transitory Art. 154c of the Constitution of the Slovak Republic, international treaties on human rights and fundamental freedoms that the Slovak Republic has ratified and were promulgated in the manner laid down by law before 1 July 2001 shall be a part of its legal order and shall have precedence over laws if they provide a greater scope of constitutional rights and freedoms; the Convention is such an international treaty.

The District Court in its application claimed that the disputed provisions of the legislation on the whole meant that the execution was not enforceable against the state property (i.e. things owned by the Slovak Republic, including financial resources, and the claims and other property rights of the Slovak Republic), funds provided from the state budget, or funds on bank accounts held in the state treasury. Therefore, almost none of the assets belonging to the state could be subject to execution, since each property value is either a thing or claim or property right. Provisions cited by the complainant provided the state (and state budget organisations, state contributory organisations, state funds, and certain other entities) total or partial immunity from distraint. This immunity has created a situation in which creditors and satisfaction of their conferred claims are fully dependent on the will of those entities that have been declared mandatory by a judicial decision. Moreover, this situation affects the rights of creditors against the state to own property and use that property in accordance with Art. 20 para. 1 of the Constitution of the Slovak Republic ${ }^{9}$, and causes disadvantage in the exercise of the right to property to creditors of one type of receivables-receivables from the state-when compared to other creditors. In contrast, the relevant legislation favours the state in protecting its property rights because the state property is almost completely protected from execution. Therefore, the District Court contested provisions by the complainant and claimed that they were in breach of Art. 20 para. 1 (property rights) in conjunction with Art. 12 para. 2 (anti-discrimination clause) of the Constitution of the Slovak Republic ${ }^{10}$ and of Art. 1 of the Additional Protocol of the European Convention on Human Rights and Fundamental Freedoms (hereinafter ECHR). ${ }^{11}$ Finally, the District Court also claimed that a part of the fundamental right to judicial protection is the right of access to execution proceedings and that the creditor requesting the recovery of their lawfully awarded debts also applies to their right to judicial protection guaranteed by Art. 46 para. 1 of the Constitution of the Slovak Republic, ${ }^{12}$ which corresponds to the obligation of courts and other designated

9 | Art. 20 para. 1 of the Constitution of the Slovak Republic: Everyone shall have the right to own property. Property rights of all owners shall be uniformly construed and equally protected by law. The right of inheritance is guaranteed.

10 | Art. 12 para. 2 of the Constitution of the Slovak Republic: Fundamental rights shall be guaranteed in the Slovak Republic to everyone regardless of sex, race, colour, language, belief and religion, political affiliation or other conviction, national or social origin, nationality or ethnic origin, property, descent or any other status. No one shall be aggrieved, discriminated against or favoured on any of these grounds.

11 | Art. 1 of the Additional Protocol of the ECHR: Every natural or legal person is entitled to the peaceful enjoyment of his possessions. No one shall be deprived of his possessions except in the public interest and subject to the conditions provided for by law and by the general principles of international law. The preceding provisions shall not, however, in any way impair the right of a State to enforce such laws as it deems necessary to control the use of property in accordance with the general interest or to secure the payment of taxes or other contributions or penalties.

12 I Art. 46 para. 1 of the Constitution of the Slovak Republic: Everyone may claim his or her right by procedures laid down by a law at an independent and impartial court or, in cases provided by a law, at other public authority of the Slovak Republic. 
authorities to deploy the legal conditions for the recovery of such claims even against the will of the subject of obligation. In this context, the District Court pointed out that the conditions for exempting certain proceedings from enforcement should not be designed to mean an exclusion of the right to judicial protection. Disputed legal norms are, therefore, also contrary in relation to the right to judicial protection in conjunction with the anti-discrimination clause of the Constitution of the Slovak Republic. ${ }^{13}$

The claim did not object the understanding of a state's execution immunity as objectively justifiable, for example, by social interests (a part of wages) or privacy issues (inviolability of personal chattels inherently interlinked with a person). The District Court did not dispute that there are reasonable and objective reasons, which may also be a reason to grant executive immunity to the state property. In the case of the state, executive immunity may be considered, for example, in relation to the property to ensure national defence and security, the property of foreign missions, the shares in strategic enterprises, and other assets, if there is a particular public interest. Consequently, defined executive immunity would certainly be an objective and reasonable justification and, thus, constitutionally consistent with Art. 12 para. 2 of the Constitution of the Slovak Republic. Contested provisions, however, provide the state with almost full immunity from execution.

\section{MAIN ARGUMENTATION LINES OF THE SLOVAK PARLIAMENT AND GOVERNMENT}

The Slovak Constitutional Court has also allowed the supreme executive authority, the Government of the Slovak Republic, to present their arguments that are similar to the usual governmental arguments presented to the ECtHR in case the principle of proportionality is to be examined. Moreover, even the supreme legislative power decided to present its arguments. ${ }^{14}$

In general, the National Council of the Slovak Republic considered the execution immunity of a state to be justified because it protects public interest by exercising public functions that cannot be blocked, as reasonable doubts would otherwise arise about the legitimacy of such a state, which is unable to fulfil its functions representing its raison d'être. The National Council analysed the situation and determined that if any state body had been affected by execution, it could have affected funding for the salaries of civil servants in a public agency; and the working capital of a state body such as computers, printers, and office furniture. If that were to happen, any public body could have not performed its duties for which it is legally obliged and would have had to face a legitimate claim by natural and legal persons for violation of their rights, which cannot be applied otherwise than through a public authority, such as the issuance of various licences and concessions or certificates, and administrative decisions. Furthermore, the National Council pointed out that the description of basal functions of the state by the District Court was

13 | Zoltan J Toth, The Methods of Statutory Interpretation in the Practice of the High Courts of Hungary. AnnalesUniversitatisMariae Curie-Sklodowska, Lublin - Polonia, vol 1, 2016, p. 173 et seq. 14 | Ibid., I.4 and I.5 respectively. 
improper and incorrect, since such an interpretation was based on missed inclusion of a contradiction between the protection of state property as public property intended for public benefit tasks on the one hand and the enforceability of rights on the other (which is, however, also secured from public funds). ${ }^{15}$

Moreover, the National Council believed that the proposal was motivated by the District Court's judicial excessive formalism in the interpretation and application of legal norms. Finally, in the particular case in question, the National Council could not see exclusion of the state from the scope of its law since the executive order was partially paid.

Following the legal reasoning usually applied by the ECtHR, the National Council noted the decision of the Slovak Constitutional Court defining public interest as an accepted reason for restricting fundamental rights and freedoms and tried to prove necessity and proportionality. The National Council was of the opinion that the contested provisions of the laws are proportionate to the aim pursued by them and, therefore, the adopted legislative measures were appropriate, although they limited the fundamental rights or freedom; nevertheless, its negative consequences balance the positives embodied in the overall public interest pursued by them. ${ }^{16}$

The government, represented by the Ministry of Justice of the Slovak Republic, stated that the purpose of the contested provisions of the legislation was to meet the needs of public interest, including the need to ensure the proper functioning of the state. According to the government, no state can function without sufficient financial resources and material base. Moreover, an argument concerning the subject and object of execution was presented, since the Ministry of Justice found it very important in relation to the right to own property-namely the fact that it is a designated administrator of the state property as a distinct person from the owner of the property, the Slovak Republic-which would be executed. The government emphasised that the Law on State Property Administration does not absolve from the responsibility to pay the financial commitment. This rule excludes only the state property employed for public and non-business purposes to be used to satisfy the creditor's claim. The government focused on the nature of the state property and the functions of the state, either internal or external. According to the government, there cannot be a state without ensuring the fulfilment of the performance of these functions because it is the state's duty to protect state property (including funds) required to carry out state tasks or in connection with the performance of its functions, and provide the public activities of benefit. If the state, through its legislative power, does not apply protection of its property (even if in a different way from others), it would lose the only instrument that could prevent destabilisation and disablement not only of public authorities (e.g. the ministries of local government, courts, and police), but, for example, disposing of hospitals, schools, and other important public institutions. Moreover, the government emphasised that the restriction only concerns the state property that can be owned only by the state and the state property earmarked for public and non-commercial purposes. State property used in the business sector (e.g. public undertakings) might be fully or partially executed; therefore, the protection of state property does not apply to all state property. ${ }^{17}$

15 | See e.g. Art. 4 of the Constitution of the Slovak Republic: Mineral resources, caves, underground waters, natural healing sources and streams are a property of the Slovak Republic.

16 | Detailed reasoning of the Slovak Parliament can be found in the Slovak CC decision, part. I.4.

17 | Detailed reasoning of the Slovak government can be found in the Slovak CC decision, part. I.5. 


\section{REASONING OF THE SLOVAK CONSTITUTIONAL COURT}

Given the reasons submitted by the complainant, concerning alleged non-compliance of executive immunity of state property with the fundamental right to judicial protection and the right to a fair trial were essentially identical to the grounds on which his arguments were based in support of the non-compliance of the existing scope of executive immunity of state property, the Slovak CC found it satisfactory to focus on one of the fundamental rights. It declared that while the legal protection of the fundamental right to property and the right to peaceful enjoyment of possessions is oriented towards the substantive legal sphere of creditor claims against the state, the right to judicial protection and the right to a fair trial must provide protection of procedural guarantees of the rights. The Slovak Constitutional Court has already clearly expressed that property rights under Art. 20 para. 1 of the Slovak Constitution also include a requirement that the proceedings concerning the protection of this fundamental right strictly respect the constitutional principles of legal certainty, equality, and non-discrimination. ${ }^{18}$ It examined in detail the legislative framework of protection of the right to property and applied it per analogiam to the right to judicial protection. ${ }^{19}$

The Slovak Constitutional Court examined the impugned legislation as a whole from historical, application, and comparative views. ${ }^{20}$ Within the specific part of the decision, the Slovak CC expressly outlined its interpretation methodology, which has made the decision very systematically processed. The Slovak CC noted that the first partial execution immunity in relation to the state property was explicitly embedded into the Slovak legislation only with legal effect from 1 January $1997 .{ }^{21}$ In one of its previous decisions, the Slovak Constitutional Court declared that public interest is a legitimate aim to restrict the right to property, and a special status of the state property is not in conflict with the constitutional principles of equality and equality of civil relations. ${ }^{22}$ Nevertheless, the Slovak CC observed that since that time, the legislation has included an increasing number of amendments to the relevant laws, even in relation to the state treasury which used to be a means to recover financial claims, but which became excluded almost without any exception from the scope of the enforcement procedure. ${ }^{23}$ Moreover, even execution in relation to the funds provided from the state budget and the budget of the European Union was limited.

While examining the situation, the Slovak Constitutional Court looked at other national legislations. This comparative argument of interpretation includes several aspects of selected legal frameworks, sometimes even their application moments. For example, in Germany, public interest is also involved; however, for state execution immunity in general, property is divided into financial and public property. Financial property might be executed if it ensures public interest only indirectly. As for the Czech Republic, it provides that the enforcement of a decision imposing a state to pay a sum of money leads to the property which the relevant commitment relates to or which has been managed by the state body

18 | Slovak CC, III. ÚS 328/05, finding from 29 March 2006.

19 | Slovak CC decision, part B.

20 | The analysis of the legislation as a whole is presented in the Slovak CC decision in part III.

21 | All previously adopted relevant legal acts upon state property, either during the communist regime or during the first years after its fall, did not cover the issue of limits of execution of State property.

22 | Slovak CC, 92/1998, finding from 3 March 1998.

23 | State Treasury Act with effect from 1 January 2003. 
whose activity has established the commitment. If the property is insufficient to satisfy the claim, an authorised person may exercise the remainder of the decision to be carried out by a garnishee order on the account of the Ministry of Finance. Moreover, budget rules impose no restrictions on the execution of the state property. The relevant Austrian legislation is identical to the legislation that was a part of the Czechoslovak legislation until 31 December 1950. According to the legislation, state administrative bodies decide which part of the municipality, or the central state body property that serves the public interest, might be executed to satisfy the creditor. In principle, the Hungarian legal regulation does not contain any distinction between execution as such and execution of state property. ${ }^{24}$ All the examples have pointed out that the compared legal frameworks have included a less absolute approach to the concept of execution immunities of a state within legal relations based on vertical subordinate relationships within a state, leaving aside to an international norm to cover interstate relations based on the horizontal relationship of equality.

Following this, the Slovak Constitutional Court emphasised its already adjudicated legal opinion, according to which the property that is the subject of protection guaranteed under Art. 20 of the Slovak Constitution includes not only things, but also rights and other assets. ${ }^{25}$ This corresponds to the ECtHR case law, according to which the term 'property' under the convention can embrace 'existing property' or assets, including claims, with respect to which the applicant can argue that they have at least a legitimate hope (expectation) to achieve the effective enjoyment of the right to property. ${ }^{26}$

This is a momentum in the decision of the Slovak Constitutional Court that reminds the reader of the case law of the ECtHR. However, this is not surprising as both courts deal with the protection of human rights and fundamental freedoms. Nevertheless, it is very interesting that after explaining the status of the right to property, the Slovak Constitutional Court applies the proportionality test that even the ECtHR did not apply in relation to the cases that included state immunity because it focused strictly on the application of the state immunity and its consequences and not on the possible variations of that application. Moreover, although the Slovak Constitutional Court considers the status of state immunity from the international law perspective and mentions, for example, the Greek Distomo case, it has obviously decided not even to note the similarly relevant International Court of Justice decision. ${ }^{27}$ It follows the usual way of balancing different interests and analyses their conflicts from various methodological perspectives.

Further according to the Slovak Constitutional Court, it is not possible to absolutely limit the fundamental right to property. However, assessment of the legitimacy of restrictions on any fundamental right or freedom means finding a balance between public and private interests. If the restriction is legitimate, there is a question of whether it is also appropriate. The Slovak Constitutional Court considered the relation between the public interest and restrictions on the fundamental rights and freedoms, and consequently expressed its

24 | For the comparison, see the Slovak CC decision, part III.11.2 - III.11.5.

25 | See finding of the Slovak CC No. II. ÚS 19/97.

26 | E.g. European Court of Human Rights, The Prince Hans-Adam II. of Liechtenstein v. Germany, application no. 42527/98, judgement, 12 July 2001, para. 83.

27 International Court of Justice, Jurisdictional Immunities of the State (Germany v Italy, Greece intervening), judgement of 3 February 2012. 
doctrinal position that the use of property for the purposes of general interest may justify a restriction on not only property rights, but also other fundamental rights and freedoms. ${ }^{28}$

In relation to the execution case, the Slovak Constitutional Court noted that it was obvious that the property in the administration of the state property administrator is legally designated for use for public and non-business tasks; thus, the legislation pursues public interest. The same might be declared in relation to the other two contested acts of legislation. In summary, the Slovak Constitutional Court finds that the legal regimes of the Law on State Property Administration, the State Treasury Act, and the Act on the Financial Regulation, including an integral part of the executive immunity of state property, are instruments for achieving public interest. For that reason, it concluded that the contested provisions of statutory legislation are legitimate in terms of the achievement of public interest and, therefore, are liable to justify restrictions on the fundamental right to property and the right to peaceful enjoyment of possessions. ${ }^{29}$

As for the proportionality test, the Slovak Constitutional Court has undertaken three phases: examination of suitability, necessity, and proportionality stricto sensu. Hence, stricto sensu proportionality was preceded by the question of whether the institute restricting certain fundamental rights can enable attaining the objective pursued was at stake, followed by determination of the criteria of necessity, desirability, or use of the least drastic means.

Nevertheless, as has already been pointed out, the Slovak Constitutional Court took the usual way of the ECtHR decision reasoning that included a proportionality test if the aim pursued had been found legitimate. Regarding the criterion of suitability, the Slovak Constitutional Court finds that the measures chosen by the legislature are likely to achieve the intended purpose. In a situation where the owner has a claim against the state and by an enforcement order, they initiate the enforcement proceedings, the executive immunityas legally defined-is an efficient barrier against the definitive elimination of the use of property for public purposes. ${ }^{30}$ Returning, therefore, to analyse the second criterion of the proportionality test, the Slovak Constitutional Court notes that, while opening enforcement proceedings (the only situation when statutory provisions of the contested application are applicable), the legal system does not know of other tools to protect the use of the concerned property for public purposes. According to the Slovak Constitutional Court, such an instrument might be a special order for a judicial bailiff to realise enforcement proceedings against the state, only in relation to its property pertaining to business purposes. However, such a legally regulated order is not stipulated, and the Slovak CC did not find any other legal possibilities to intervene more agreeably with the property rights while maintaining the reviewed execution immunity of a state. Finally, the criterion of necessity of using the least drastic means was also satisfied, despite the fact that the extent of all three contested legal norms gradually shortened the list of units that could be executed. ${ }^{31}$

Moving to the proportionality stricto sensu, the Slovak Constitutional Court decided to apply several arguments, namely empirical, systematic, and contextual. ${ }^{32}$ In the opinion of the Slovak CC, regulatory developments concerning execution immunity of state assets

28 | Compare another Slovak CC decision, PL. ÚS 11/96.

29 | The Slovak CC decision, part IV, 1.3.4.

30 | The Slovak CC decision, part IV, 1.4.1.

31 | The Slovak CC decision, part IV,1.4.2.

32 | The Court followed methodological approach of the ECtHR. See the Slovak CC decision, part IV, 1.4.3. 
show strong links between the rules embodied in the contested provisions, which provide truly effective and comprehensive protection of state property. However, this is a result of a gradual, poorly controlled development by legislative amendments, rather than a conscious and deliberate legislative act responding to negative practical experiences requiring effective legislative solutions. Regarding the evaluation of creditors' experience in enforcing their claims against the state, the Slovak CC concluded that although there would not be an absolute a priori impossibility of execution of state property, there is an indication of extraordinary difficulties in the legal process of claiming their satisfaction. The difficulty is undoubtedly particular in the case of lower amounts, and it usually leads a creditor to resign from their own efforts to bring the satisfaction of their claims adjudicated to fruition. ${ }^{33}$

When analysing systemic arguments, the Slovak CC found it necessary to focus attention on two topics: executive immunity upon state property and the importance of the fundamental right to property. It is interesting to point out here that the Slovak CC noted the procedural character of the institute of immunities that is a bar to the proceedings; however, according to the Slovak CC, it would be a pure formalistic approach if it ignored the significant impact of reviewed execution immunity on the property rights of the creditors. Such an approach is expressly opposite to the position of the International Court of Justice; it is even more interesting that the Slovak CC has not mentioned the International Court of Justice even here; it just determined itself with such an opinion within the lines of its decision. ${ }^{34}$

As for immunity, the Slovak CC emphasised that the relevant law had been elaborated mainly in the international law area, based on the application of the principle par in parem non habet imperium and is interlinked with the principle of sovereign equality of states. ${ }^{35}$ The Slovak CC noted in accordance with the general understanding that the overall concept of state immunity in the 20th century had mostly been replaced by more restrictive approaches, the development of which was initiated by distinguishing acts of sovereign states on the one hand (acta iure imperii) and national private law acts (acta jure gestionis) on the other. It is not surprising that the Slovak CC sees a restrictive understanding based on the number of international legal documents, such as the European Convention on State Immunity from 1972 and the United Nations Convention on Jurisdictional Immunities of States and Their Property from 2004. However, it is surprising again that this part of the decision does not include any reference to the International Court of Justice decision ${ }^{36}$ at least to explain why it is not relevant, for example, by claiming in general terms that the current decision focuses on the possible use of financial assets related to acta iure gestionis (state property used for commercial activities and only indirectly protecting the public interest) and does not deal with acta iure imperii as such (of course, a proper reasoning of this claim would have had to follow) or that it is the domestic affair since the dispute is not related to the relationship of more states, but only a position of one state in front of its own judicial authorities. However, the Slovak CC decided to refer to the ECtHR jurisprudence, although, first, it related exactly to the relationship of more states and, second, its decisions have been based mostly on the procedural aspects of the analysed international law concept of jurisdictional immunities of a state.

33 | See e.g. another decision of the Slovak CC, No. II. ÚS 194/08.

34 | The Slovak CC decision, part IV, 1.4.3.

35 | Ibid., part IV, 1.4.3 i).

36 | International Court of Justice, Jurisdictional Immunities of the State, Germany v Italy: Greece intervening, judgement of 3 February 2012 
Methodologically, this might be considered the most controversial part of the decision since it includes a misunderstanding of the basic background of jurisdictional immunities of states. ${ }^{37} \mathrm{Jurisdictional} \mathrm{immunities} \mathrm{of} \mathrm{states} \mathrm{reflect} \mathrm{the} \mathrm{current} \mathrm{status} \mathrm{of}$ sovereign states within international law, namely sovereign equality and independence of these supreme subjects of international law ${ }^{38}$ and the principle of non-interference. ${ }^{39}$ As has already been pointed out, looking for a solution while exercising these principles in the area of coexistence and, in particular, cooperation among states has resulted in the approach par in parem non habet imperium, i.e. there is no jurisdictional power of a sovereign over another sovereign. However, the issue before the Slovak CC concerned the situation of a legally subordinated subject in relation to a state. Legal principles to be applied here are different in this relationship, although the Slovak CC admitted that the relationship between the claimant and the state is not equal. Nevertheless, using logical terminology, the Slovak CC connected the fact that there is a relationship of inequality with the requirement that the tighter the review of the so-called inner immunity of a state must be. Despite the terminology used, the connection has been as if pretended because such an approach ignores the understanding and background of both the concepts.

The Slovak CC has preferred providing comments and presenting its understanding of the case of Al-Adsani v United Kingdom and the importance of this judgement from 2001 within the development of state immunity rules. It emphasised that the decision according to which the rule governing state immunity is a generally recognised rule of international law, and therefore the granting of state immunity cannot be described as disproportionate and therefore contrary to the criterion of proportionality, was adopted only by a majority of one vote. Consequently, it focused on the dissenting opinions of judges and on the following relevant decision of the ECtHR upon state immunity, which followed its stable case law established by the Al-Adsani case. ${ }^{40}$

37 | It is not only the Slovak Constitutional Court that shares this misunderstanding of jurisdictional immunities of States. As if encouraged by the analysed decision of the Slovak Constitutional Court, the Supreme Court also-even more flagrantly-interchanged the concept of jurisdictional immunities of States with diplomatic immunities of State agents. See Supreme Court of the Slovak Republic, decision published under No.157/1964 Zb.

38| See United Nations Charter, Art. 2. para 1: The Organisation is based on the principle of the sovereign equality of all its Members.

39 | Ibid., para. 7: Nothing contained in the present Charter shall authorize the United Nations to intervene in matters which are essentially within the domestic jurisdiction of any state or shall require the Members to submit such matters to settlement under the present Charter; but this principle shall not prejudice the application of enforcement measures under Chapter Vll.

40 | The relevant case Kalageropoulou and Others v Greece and Germany was considered from the perspective of an individual and their legal application activities that were also subject of the decision of the Greek AriosPagos (Greek Supreme Court), which on 4 May 2000 upheld the firstinstance court's decision of 30 October 1997. It was the decision that entitled Voiotia Prefecture and another plaintiff to compensation from the Federal Republic of Germany for murders and damage to property caused during the World War II by German occupation in the village of Distomo. Both Greek court decisions were based mostly on the same view that granting state immunity in case of breach of peremptory norms of international law is an abuse of the right to immunity. However, at the end of the procedure, the Greek government authority (Minister of Justice) did not grant an approval for enforcement, which lead those entitled to bring a complaint to the ECHR (European Court of Human Rights, Kalageropoulou and Others v Greece and Germany, application no. 59021/00, decision on inadmissibility, 12 December 2002). 
In case of some international treaties, Slovakia is a country of a monistic rather than dualistic system of relationship between international and national law; some international treaties are not only directly applicable, but also have primacy over national laws (not the Slovak Constitution). ${ }^{41}$ By its approach in the actually analysed decision, the Slovak CC probably followed Art. 1 para. 2 of the Slovak Republic and acknowledged and adhered to the general rules of international law, international treaties by which it is bound, and its other international obligations in such a way that it formalistically applied rules having the same name but different content.

Instead of challenging the legal opinion of another important international judicial body, the Slovak CC continued with its line of reasoning and pointed out that the fundamental right to property as the second element of systemic examination of the argument is considered to be a standard part of the constitutional catalogue of fundamental rights and freedoms of democratic countries having the ambition to apply rule of law. ${ }^{42}$ The Slovak Constitutional Court held that modern democracy is characterised by respect for property rights and the principles of market economy. ${ }^{43}$ The Slovak CC, therefore, analysed the property element within the systematic argument in detail, including contextual and value-based argumentation.

It pointed out its legal opinion on the direct and exclusive legal control over things to be the substance of the property right. ${ }^{44}$ Moreover, it underlined the opinion that in terms of the social market economy and democratic rule of law, which are clearly proclaimed in the Constitution and further projected into several laws, the property right includes a free opportunity to acquire ownership and other rights over things (in Slovakia with the exception of cases falling under Art. 4 of the Constitution upon the exclusive ownership of the Slovak Republic (e.g. mineral resources) and a freedom to realise legal authority over acquired property that can only exceptionally be limited with regard to the existence of social interest, specifically public interest. ${ }^{45}$ The Slovak Constitutional Court, thus, examines the social function of property and comes to the conclusion that the function of ownership is essentially conceived not only individualistically but also in terms of the interests of a citizen of a state as a whole. The decision includes several academic works in this context and a decision of the German Federal Constitutional Court that went on to say that in determining the content and boundaries of ownership, the legislator has the right to carry out a social model, stemming from both the guarantees of private property and their social ties. ${ }^{46}$ It is interesting that the Slovak CC found it relevant to include this judgement, although it admitted that cited decisions did not result from decision-making

41 | See decision of the Slovak CC, II. ÚS 91/1999, ruling from 16 December 1999 based mostly on Art. 7 para. 5 of the Slovak Constitution: International treaties on human rights and fundamental freedoms, international treaties for whose exercise a law is not necessary, and international treaties which directly confer rights or impose duties on natural persons or legal persons and which were ratified and promulgated in the way laid down by a law shall have precedence over laws.

42 | The Slovak CC decision, part IV, 1.4.3 ii).

43 I It was decided so also in the previous decision of the Slovak Constitutional Court III. ÚS 243/2010, 26 January 2011.

44 | Compare e.g. another Slovak CC decision PL. ÚS 30/95, 2 April 1996.

45 | Ibid.

46 | The Federal Constitutional Court of Germany decision of 23 April 1974, $1^{\text {st }}$ Senate, 1 BvR 6/74 and 2270/73 is available at: http://www.servat.unibe.ch/dfr/bv037132.html [online accessed 7September 2021]. 
activities directly related to state property. Nevertheless, they were considered to be a useful interconnection because the aim of the Slovak CC was the statutory regulation of property ownership associated with the state. This regulation is specific because it serves as a binding law to regulate the ownership of assets. It is true that a state does not have any other real tool to influence the exercise of its right to property; ${ }^{47}$ however, very careful consideration is required. This requirement is particularly important in relation to the legal regulation of the status of state property in an enforcement process of a judicial decision, which by definition implies a fault in the process of realisation of a particular legal relationship; in this case, the fault was caused by a state and another procedural barring norm that would cause the failure to fulfil the right confirmed by a judicial decision. ${ }^{48}$ By disproportionately favouring a legal position of its own property at the expense of the legal status of a property of another owner, the government can undermine the constitutional guarantees of property rights of individual creditors and, thus, the social aspect of ownership.

The systematic argument of examination of a fair balance between the fundamental right to property and the right to peaceful enjoyment of possessions on the one hand and assessed scope of execution immunity of state property on the other refers to the apparent tendency to reduce state immunity in international legal terms. In the opinion of the Slovak Constitutional Court, it should be more stringent when assessing the (internal) immunity protecting states, since it is assessed with respect to the subordinate entities forming the state's personal substrate, namely the relationship where the already mentioned principle par in parem non habet imperium expressing equality of states as subjects, international law is not applicable. The systematic argument similarly indicates the need to consider the width of the impact of the contested restrictions over the fundamental right to property, which are not limited to the individual sphere of the relevant creditor, but through limitations towards the satisfaction of their pecuniary claim, they influence the quality and quantity of their contribution to the development of the social environment as a whole. ${ }^{49}$

Having outlined the understanding and assessment of the system, the systemic argument proceeds effortlessly to a contextual argument. The mere failure to comply with legally adjudicated and enforceable obligations, regardless of the nature of the subjects of legal relations, according to the Slovak CC, is not only an undesirable but also a harmful phenomenon in the context of rule of law. ${ }^{50}$ If the ability of a creditor to make use of an effective means to recover the debt is drastically limited, the negative development of the quality of the concerned legal relationship cannot be justified by the rule of law. ${ }^{51}$

Moreover, when the contextual argument has steered the attention of the Slovak Constitutional Court towards the negative effects of restrictions on fundamental rights as a result of prioritising the public interest, it is appropriate to look at other possible impacts of unenforceability, respectively significant restrictions on enforcement of claims vis-avis a state. These are mainly oriented towards the economic sphere, where, depending on the amount of the claim of the injured creditor, such an approach can directly affect

47 | See another Slovak CC decision PL. ÚS 28/00,10 January 2002.

48 | The Slovak CC decision, end of the part IV, 1.4.3 ii).

49 | The Slovak CC decision, part IV, 1.4.3 iii).

50 | Ibid.

51 | Ibid. 
economic activity in a broad sense, thus indirectly affecting the economic background of other subjects of law. Furthermore, non-legal aspects of trust of entities forming a personal substrate of a state may adversely affect the level of performance of public duties to the country (e.g. with respect to tax). ${ }^{52}$

Moving to value-based arguments, sometimes even called non-legal arguments, it looks as if the Slovak Constitutional Court decided to include as many arguments as possible. It is submitted that this argument could have been elaborated more since it is actually based on the principles of legal society. The Slovak CC has stressed that the simple legal principle according to which the debtor is obliged to fulfil their commitment must be protected by the legislature. If the debtor fails to comply with their commitment voluntarily, it is important to provide the creditor with effective remedies to satisfy their fundamental right to property. It is even more important if the debtor is a state that should exercise its powers to guarantee the enforcement of legal obligations. If the state as a rule-maker benefits itself to the extent that the creditor is not able, or able only with great difficulty, to have the execution realised, although the property claims are reasonably expected, the value system of the society clearly rewards the creditor's interest in preserving the object and purpose of the fundamental right to property to the public interest in the protection of state property against its withdrawal from performance of public functions. ${ }^{53}$ This argumentation line is more comprehensible than an argument based on an international law concept of jurisdictional immunities of a state, since used concepts are similar in terminology but distinct in their background and substance.

It is true that the Slovak Constitutional Court has recognised that the state is a sui generis legal entity and, as suggested by the Parliament and government, an exercise of its official authority necessarily implies a certain asset base, which is intended to be protected on purpose. However, it must be noted that this protection is provided by means, which are limited by the rule of law embedded in a constitutional order, with its integral part represented by a catalogue of fundamental rights and freedoms. ${ }^{54}$

Without calling into question the concept of increased level of protection of state property, the Slovak Constitutional Court has noted that the examined protection must be adequate. It has found it unacceptable that persons acting with a state in legal relations concerning an asset are not guaranteed effective and efficient satisfaction of their property claims. Otherwise, the fundamental right to property and the right to peaceful enjoyment of property of such persons move into a position of illusion, not reality. These natural or legal persons who are in legal relations pertaining to the state fulfilling its obligation can then only hope that the state meets this voluntarily. ${ }^{55}$

Finally, to present the formal outcome of the proceedings in front of the Slovak Constitutional Court, it was decided that the concept of execution of immunity of state property that is cumulatively embodied in several legal acts has, therefore, been identified as non-complying with constitutional requirements, stemming from the rule of law (Art.1 para.1 of the Slovak Constitution), the fundamental right to property (Art. 20 para.1 of the Slovak Constitution), and the fundamental right to judicial protection (Art. 46 para. 1 of the Slovak Constitution), since the right to a fair trial includes the right to enforcement

52 | Ibid.

53 | The Slovak CC decision, end of part IV, 1.4.3 iii).

54 | The Slovak CC decision, part IV, 1.4.3 iv).

55 | Ibid. 
of judicial decisions. Moreover, the Slovak CC points out the effect that one group of recipients of legal norms regulating the enforcement of decisions are treated differently from creditors that have debtors other than the state. Dissimilarity of the treatment lies in the disproportionate restrictions and withdrawals, or even the inability of such creditors to obtain satisfaction with their confirmed executive claims if the state does not satisfy them voluntarily. ${ }^{56}$

\section{CONCLUSION}

Coming to a conclusion about the selected decision of the Slovak Constitutional Court, it is important to point out that one of the highest judicial authorities of Slovakia appears as if it has decided not to consider the relevant decision of the International Court of Justice adopted earlier that year when this International Court of Justice decision was discussed profoundly. The Slovak Constitutional Court has taken a completely different approach to decide upon the relationship of the executive immunity of a state and a fundamental right to property and judicial protection, different even from the approach of the ECtHR. This approach analyses the application of the principle of proportionality, nevertheless, the Slovak CC as if generalised application of the principle of proportionality in relation to fundamental rights protection as such.

Jurisdictional immunity of a state is a rule of customary international law which has been created and shaped on the basis of the principle par in parem non habet impperium. The practice of states was examined in the case Jurisdictional Immunities of States by the International Court of Justice, which concluded that the application practice has not yet established an exemption or rather a new rule in relation to the application of the jurisdictional immunity of States in case of infringement of mandatory rules governing basic human rights protection.

Few months following the decision of the International Court of Justice in 2012 based on jurisdictional immunities as a procedural bar to judicial proceedings, the Slovak Constitutional Court held legal standards applying executive immunity as a part of jurisdictional immunities unconstitutional and, therefore, inapplicable. Nevertheless, this decision was not based on the argument that they did not allow execution and, therefore, were not effective in relation to property rights protection or judicial protection but on the argument of application of the principle of proportionality not having met the test of proportionality. Thus, it has not followed either a usual approach of the ECtHR based on the principle of proportionality, since the ECtHR has decided not to apply it exactly in the decisions in the area of state immunity. Nevertheless, to support its argumentation, the Slovak Constitutional Court has applied several means of interpretation; and expressly mentioned historical, comparative, and systemic arguments, including contextual and value-based interpretations. Moreover, without naming them, the Slovak CC has also pointed out its own case law and scholarly works.

Having said that, it is submitted that external systemic and comparative arguments have been applied not the way the original decision makers intended. As only a list of other supreme judicial bodies at the national and international level was on the to-do-list of the 
Slovak Constitutional Court since presented decisions and reasonings were mentioned but not critically and comprehensively compared and analysed. The presented article has pointed out this understanding of the selected decision of the Slovak Constitutional Court in relation to the jurisdictional immunities of a state applicable within interstate relations between sovereign equals if compared to the execution immunities of a state within national jurisdiction with a state as a superior participant of judicial proceedings. 


\section{Bibliography}

Alexy, R. (2010) A Theory of Legal Argumentation. Rev. ed. Oxford: Oxford University Press

Toth, Z. J. (2016) 'The Methods of Statutory Interpretation in the Practice of the High Courts of Hungary', Annales Universitatis Mariae Curie-Sklodowska, Lublin - Polonia, 1, p. 173-201

\section{Legal sources}

Convention for the Protection of Human Rights and Fundamental Freedoms, concluded on 4 November 1950, 213 U.N.T.S. 222

| Charter of the United Nations, adopted on 26 June 1945, 1 U.N.T.S. 16

International Court of Justice, Jurisdictional Immunities of the State, Germany v Italy: Greece intervening, judgement of 3 February 2012.

European Court of Human Rights, Al-Adsani v the United Kingdom, application no. 35763/97, judgement, 21 November 2001

European Court of Human Rights, Soering $v$ the United Kingdom, application no. 14038/88, judgement, 7 July 1989

European Court of Human Rights, The Prince Hans-Adam II. of Liechtenstein v. Germany, application no. 42527/98, judgement, 12 July 2001

European Court of Human Rights, Kalageropoulou and Others v Greece and Germany, application no. 59021/00, decision on inadmissibility, 12 December 2002

The Federal Constitutional Court of Germany decision of 23 April 1974, $1^{\text {st }}$ Senate, 1 BvR 6/74 and 2270/73

| Constitution of the Slovak Republic 460/1992 Coll.

| PL. ÚS 111/2011, finding from 4 July 2012

| III. ÚS 328/05, finding from 29 March 2006

| No. 92/1998, finding from 3 March 1998

| II. ÚS 91/1999, ruling from 16 December 1999

| III. ÚS 243/2010, 26 January 2011

| PL. ÚS 30/95, 2 April 1996

| PL. ÚS 28/00, 10 January 2002

| Supreme Court of the Slovak Republic, decision published under No. 157/1964 Zb. 